\title{
Are c-erb B2 and UGCG Reliable Immunohistochemical Markers Of Canine
}

\author{
Mammary Carcinomas?
}

\author{
Emin KARAKURT ${ }^{1 a}{ }^{\boxplus}$, Mushap KURU $^{2 b}$, Serpil DAG ${ }^{1 c}$, Enver BEYTUT ${ }^{1 d}$, Hasan ORAL ${ }^{2 e}$, \\ Hilmi NUHOGLU' ${ }^{1 f}$ Ayfer YILDIZ ${ }^{1 g}$
}

1. Kafkas University, Faculty of Veterinary Medicine, Department of Pathology, Kars, TURKEY.

2. Kafkas University, Faculty of Veterinary Medicine, Department of Obstetrics and Gynecology, Kars, TURKEY.

ORCID: 0000-0003-2019-3690a , 0000-0003-4409-251X b, 0000-0001-7667-689Xc, 0000-0003-3360-2940d, 0000-0002-4366-4988 , 0000$0003-2530-2542^{f}, 0000-0002-6569-5435^{g}$

\begin{tabular}{lc}
\hline $\begin{array}{c}\text { Geliş Tarihi/Received } \\
\text { 14.12.2020 }\end{array}$ & Kabul Tarihi/Accepted \\
06.04 .2021 & Yayın Tarihi/Published \\
31.10 .2021
\end{tabular}

Abstract: In this study, we aimed to correlate c-erb B2, UGCG expressions and tumor size in canine mammary tumors. The material of this study consisted of tissue samples of mammary carcinomas taken from ten female dogs brought to our department between 2012-2020. Avidin-Biotin Peroxidase method was used as an immunohistochemical method. All canine mammary tumor cases were immune positive for c-erb B2 and UGCG reactions. We detected membranous and cytoplasmic c-erb B2 immune positive staining in the neoplastic epithelial cells. Reactions were moderate to strong in severity. We observed strong dark brown cytoplasmic ceramide glucosyltransferase staining in the cytoplasm of neoplastic epithelial cells. We found that the increase in the number of c-erb B2 and UGCG immune positive cells paralleled the tumor size. In conclusion, the increase in the number of c-erb B2 and UGCG positive cells in direct proportion to the tumor size, which is an important diagnostic parameter in canine mammary tumors, made us think that c-erb B2 and UGCG could be reliable immunohistochemical markers in the diagnosis of canine mammary tumors. In addition, these markers must be evaluated comprehensively in line with different cancer diagnosis parameters.

Keywords: Canine, c-erb B2, Mammary Tumor, UGCG.

\section{c-erb B2 ve UGCG Köpeklerin Meme Karsinomlarında Güvenilir İmmunohistokimyasal Markerlar Mıdır?}

Öz: Bu çalışmada, köpek meme tümörlerinde c-erb B2, UGCG ekspresyonları ve tümör boyutu arasında ilişki kurmak amaçlandı. Çalışmanın materyali; 2012-2020 yılları arasında Anabilim Dalımıza getirilen 10 dişi köpekten alınan meme kanseri dokusu örneklerinden oluştu. İmmünohistokimyasal yöntem olarak Avidin-Biotin Peroksidaz yöntemi kullanıldı. Tüm köpek meme tümörü vakaları c-erb B2 ve UGCG reaksiyonları yönünden immun pozitifti. c-erb B2 ve UGCG immun pozitif hücre sayısındaki artışın tümör boyutuna paralel olduğu tespit edildi. Neoplastik epitel hücrelerde membranöz ve sitoplazmik c-erb B2 immün pozitif boyamalar tespit edildi. Reaksiyonların şiddeti orta ila şiddetli düzeydeydi. Neoplastik epitel hücrelerinin sitoplazmasında şiddetli koyu kahverenginde sitoplazmik seramid glukoziltransferaz boyaması tespit edildi. C-erb B2 ve UGCG immün pozitif hücre sayısındaki artışın tümör boyutuna paralel olduğu ortaya konuldu. Sonuç olarak, köpek meme tümörlerinde önemli bir tanı parametresi olan tümör boyutu ile doğru orantılı olarak c-erb B2 ve UGCG pozitif hücre sayısındaki bu artış, bize köpek meme tümörlerinin teşhisinde c-erb B2 ve UGCG'nin güvenilir immunohistokimyasal belirteçler olabileceğini düşündürdü. Ek olarak bu belirteçlerin, farklı kanser tanı parametreleri doğrultusunda kapsamlı bir şekilde değerlendirilmesi elzemdir.

Anahtar Kelimeler: c-erb B2, Köpek, Meme Tümörü, UGCG.

\footnotetext{
Emin Karakurt

Kafkas University, Faculty of Veterinary Medicine, Department of Pathology, Kars, TURKEY.

e-mail: mehmeteminkarakurt@hotmail.com
} 


\section{INTRODUCTION}

C anine tumors have increased in the last decade and caused significant clinical problems $(1,2)$ As in women, mammary neoplasms are the most common tumors detected in unsprayed bitches or bitches and approximately half of these tumors are malignant $(3,4)$. The degree of malignancy is based not only on the histologic type but also on a significant amount of nuclear and cellular pleomorphism, mitotic index, presence of necrotic areas, peritumoral and lymphatic invasion, and regional lymph node status $(1,5)$. Various risk factors such as hormonal, nutritional, and genetic factors have been found to play an important role in the etiology of the tumor (2). Biomarkers are used in canine mammary tumors because of their heterogeneous morphology and biological behavior and these biomarkers assist in early diagnosis, staging, prognosis and evaluation of response to treatment (1).

Changes in genes encoding growth factors, growth factor receptors and cellular proliferation regulators have been identified to play an important role in tumorigenesis in both humans and canine mammary carcinomas (6). c-erb B2 (also known as, HER-2/neu, HER-2) is a protooncogene encoding a tyrosine kinase receptor protein that belongs to human epidermal growth factor receptors, which play an important role in the regulation of basic cellular processes such as differentiation, survival and cell development $(7,8)$. Overexpression of c-erb B2 has been detected in $20-30 \%$ of human breast carcinoma cases and positively correlated with poor prognosis $(9,10)$. During mutations in this gene, the intracellular signal cascade of the growth factor receptor becomes over-activated. As a result, tumor cells proliferate more rapidly and cancer patients develop a resistance to chemotherapeutic drugs (11). Although the prognostic value of c-erb B2 in various histological types of canine mammary tumors has been reported, unlike human breast tumor cases, there are no abundant studies of the same oncogene in veterinary medicine. $(12,13)$. c-erb B2 is also amplified or overexpressed in canine mammary tumors. However, some researchers found a direct relationship between c-erb B2 expression and poor prognosis, while some researchers reported that cerb B2 overexpression was associated with a higher rate of survival $(14,15)$.

Despite recent advances in the treatment of breast cancer, multidrug resistance (MDR) development to chemotherapy is the primary cause of therapy unsuccess $(16,17)$. Ceramide acts as a tumor suppressor lipid and induces tumor apoptosis. Ceramide is the substrate of UGCG to produce glucosylceramide that functions antagonistically with ceramide (16). Ceramide glucosyltransferase (UGCG) is closely related to MDR that develops in many types of cancer (18). In addition, it has been reported that overexpression of UGCG causes excessive proliferation of breast cancer cells (19).

In this study, we aimed to correlate c-erb B2, UGCG expressions and tumor size. Thus, we will open to discussion whether c-erb B2 and UGCG are reliable biomarkers in canine mammary tumors in line with the data obtained from our study.

\section{MATERIALS and METHODS}

\section{Animals}

The material of this study consisted of tissue samples of mammary carcinomas taken from ten female dogs brought to our department between 2012-2020.

\section{Ethical Approval}

The ethics committee report of this study was obtained from Kafkas University Animal Experimentals Local Ethics Committee (Authorization number: KAU-HADYEK-2020/076).

\section{Immunohistochemistry}

Avidin-Biotin Peroxidase method was used as an immunohistochemical method. For immunohisto 
chemical staining, the sections of $4 \mu \mathrm{m}$ in thickness taken to poly-L-lysine coated slides were deparaffinized and rehydrated in graded alcohols. In order to prevent endogenous peroxidase activity, the sections were treated with a $3 \%$ hydrogen peroxide solution in Phosphate Buffered Saline (PBS) for 15 minutes. For antigen retrieval, the sections were boiled in Citrat Buffer Solution (pH 6) for 25 min in the microwave oven (at 800 watt). In order to prevent nonspecific staining, the sections were incubated for 10 min with non-immune serum at room temperature. Diluted antibodies were incubated overnight $\left(+4{ }^{\circ} \mathrm{C}\right.$ in the refrigerator). The sections were washed 3 times in PBS solution for 5 minutes, and the biotinylated secondary antibody was applied to them at room temperature for 10 minutes. After washing in PBS (3-5 min), all sections were incubated with peroxidase-bound Streptavidin for 10 minutes at room temperature. A solution of 3.3-diaminobenzidine tetrahydrochloride (DAB) was used as a chromogen for 15 minutes. The sections were treated with Mayer's Hematoxylin for 30 seconds and washed in running water for $5 \mathrm{~min}$, dehydrated in graded alcohols, cleared in xylene and coated with entellan. Primary antibodies were omitted from the negative control sections and were treated with diluted normal serum. The slides prepared after the covering were examined under a light microscope and photographed via the Cell^P program. Analyzes of the images were done with Image J Program.

Analysis of immunohistochemical staining results; c-erb B2 and ceramide glucosyltransferase immunoreactivities were scored by the number of positive cells in the areas that best reflect the character of staining. For quantification of the immunostaining in the tissue, the analysis was started on the basis of high-intensity reaction areas. For each sample, 5 different areas were examined at a total enlargement of 200 . The number of cells stained positively in each area was recorded and the average of these 5 sites was taken as the data of that animal.

\section{RESULTS}

Immunohistochemical Results

Average numbers of immune positive c-erb B2, ceramide glucosyltransferase and tumor sizes for all animals are shown in Table 1. We did not observe any significant c-erb B2 expression in normal mammary tissue. All canine mammary carcinoma cases were positive for c-erb B2 reactions. We detected membranous and cytoplasmic c-erb B2 immune positive staining in the neoplastic epithelial cells. Reactions were moderate to strong in severity (Fig. 1A-B). Similar to c-erb B2 results, we also did not detect any considerable ceramide glucosyltransferase immune positive reactions in normal mammary tissue. All canine mammary tumor cases were positive for ceramide glucosyltransferase expressions. We observed strong dark brown cytoplasmic ceramide glucosyltransferase staining in the cytoplasm of neoplastic epithelial cells (Fig. 2AB).

Table 1. Average c-erb B2/ceramide glucosyl transferase immune positive cell numbers of the canine mammary carcinoma cases and tumor sizes.

Tablo 1. Köpek meme tümörü vakalarına ait c-erb B2/UGCG pozitif hücre sayıları ve tümör boyutları.

\begin{tabular}{cccc}
$\begin{array}{c}\text { Case } \\
\text { number }\end{array}$ & c-erb B2 & $\begin{array}{c}\text { Ceramide } \\
\text { glucosyl } \\
\text { transferase }\end{array}$ & $\begin{array}{c}\text { Tumor } \\
\text { sizes }\end{array}$ \\
\hline Case 1 & 260 & 524 & $<3 \mathrm{~cm}$ \\
Case 2 & 252 & 564 & $<3 \mathrm{~cm}$ \\
Case 3 & 344 & 680 & $3-5 \mathrm{~cm}$ \\
Case 4 & 606 & 1218 & $>5 \mathrm{~cm}$ \\
Case 5 & 374 & 714 & $3-5 \mathrm{~cm}$ \\
Case 6 & 626 & 1258 & $>5 \mathrm{~cm}$ \\
Case 7 & 356 & 650 & $3-5 \mathrm{~cm}$ \\
Case 8 & 220 & 506 & $<3 \mathrm{~cm}$ \\
Case 9 & 308 & 1018 & $<3 \mathrm{~cm}$ \\
Case 10 & 244 & 628 & $<3 \mathrm{~cm}$ \\
\hline
\end{tabular}



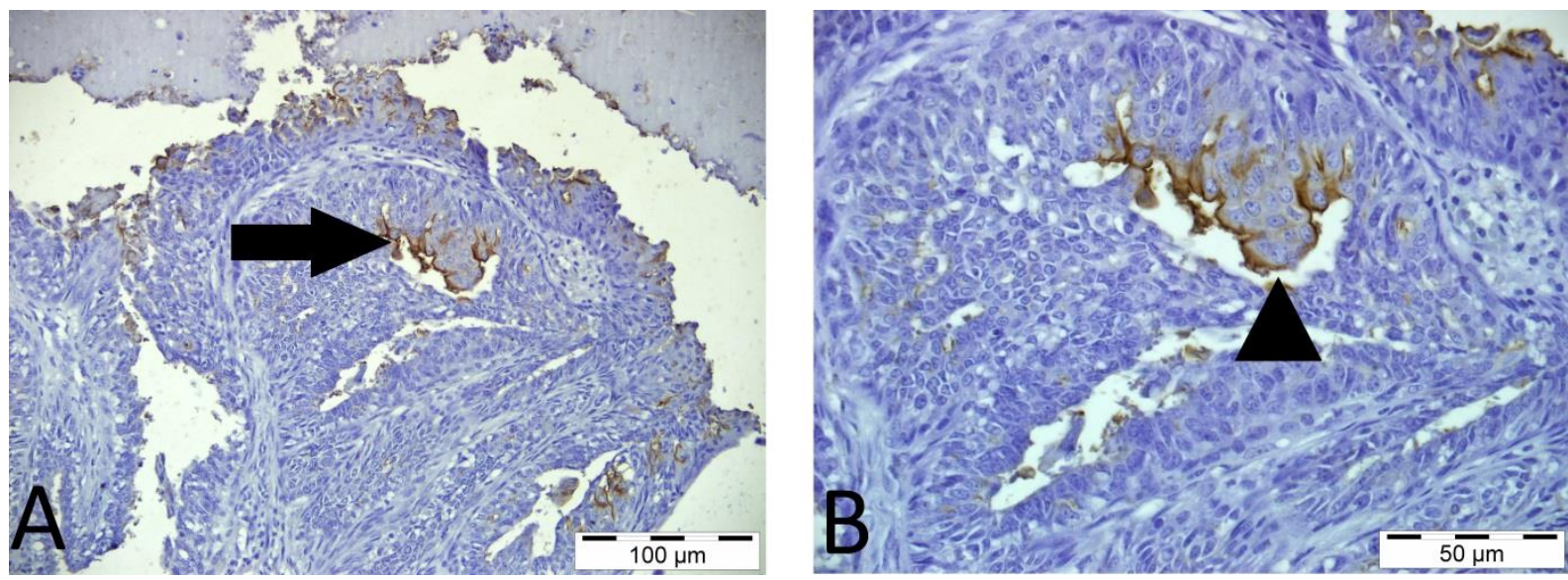

Figure 1. Dog mammary carcinoma, IHC, c-erb B2 staining, membranous reactions (arrow) in tumoral cells (A), Higher magnification, immune positive expressions (arrowhead) (B).

Şekil 1. Köpek meme karsinomu, IHK, c-erb B2 boyaması, tümoral hücrelerde membranöz reaksiyonlar (ok) (A), Daha yüksek magnifikasyon, immun pozitif ekspresyonlar (ok başı) (B).
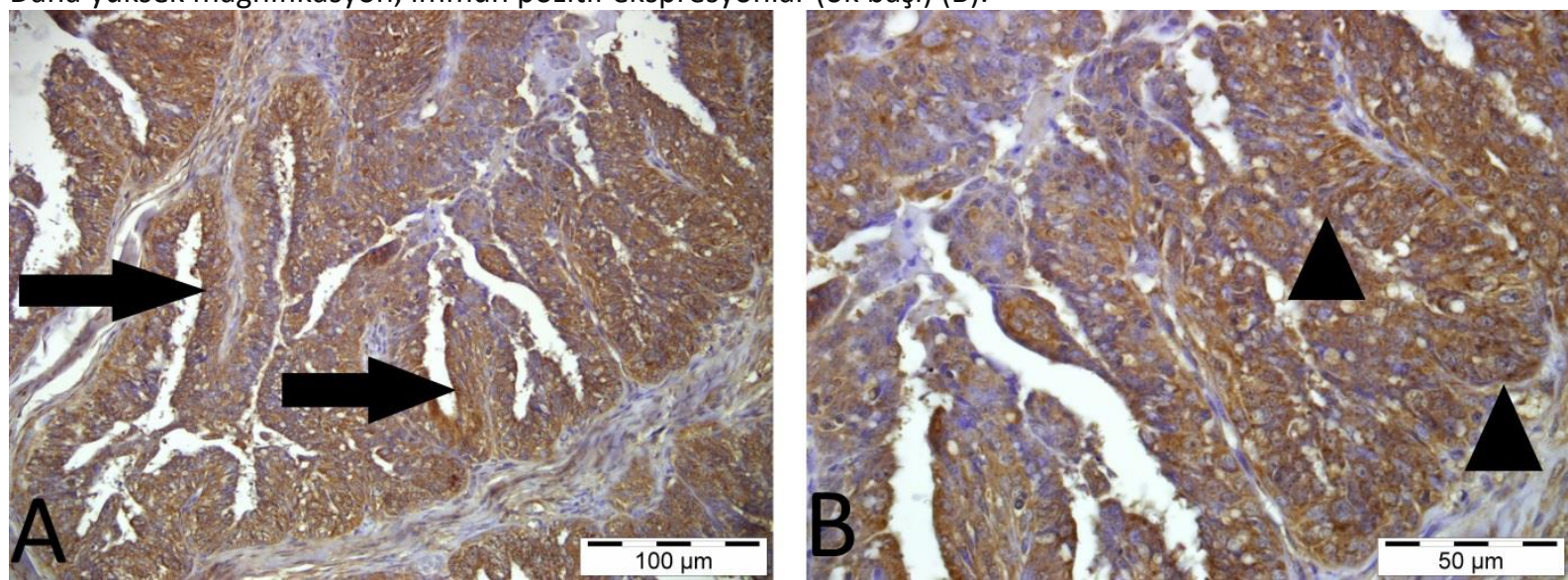

Figure 2. Dog mammary carcinoma, IHC, ceramide glucosyltransferase staining, cytoplasmic reactions (arrows) in tumoral cells (A), Higher magnification, severe dark brown immune positive expressions (arrowheads) (B).

Şekil 2. Köpek meme karsinomu, IHK, seramid glukoziltransferaz boyaması, tümoral hücrelerde sitoplazmik reaksiyonlar (oklar) (A), Daha yüksek magnifikasyon, şiddetli koyu kahverengi immun pozitif ekspresyonlar (ok başları) (B).

\section{DISCUSSION and CONCLUSION}

Biomarkers are usually proteins that can be measured in tissues such as tumors or blood and can provide information about the presence of any disease, treatment results, or prognosis. However, all cancer cells express specific proteins, also known as tumor-related antigens (2). Canine mammary tumors are less lethal than humans and cats, but researchers are trying to develop the most sensitive and specific prognostic biomarkers to detect tumor growth and metastasis (12). Although immunohistochemical staining is routinely used in the prognosis of human breast tumors and in determining the neoplastic existence, aggressiveness and best treatment method for patients, this method is not routinely used in canine mammary tumors. However, in the last decade, there has been a remarkable increase in the number of studies that have tested diagnostic and prognostically reliable biomarkers $(15,20)$. Due to the highly heterogeneous morphology and biology of canine mammary cancer cells, it is difficult to demonstrate the most suitable and useful biomarker (2).

Protooncogenes are normal genes responsible for regulating cell proliferation, but their mutant forms, oncogenes (changes in structure and 
expression), cause malignant transformation. C-erb B2, c-MYC, c-RAS, and RR1 can be given as examples of important oncogenes involved in mammary carcinogenesis $(21,22)$. Genes of the protein kinase family, which control cell growth by phosphorylating tyrosine or serine / threonine residues on proteins. Amplification and overexpression of these genes (cyes and c-erb B2) have been detected in the initiation and progression of tumors (22).

The epidermal growth factor family of growth factors bind to and activate receptors called ErbB1, ERbB2, ERbB3, and ERbB4 (23). ERbB2 (also known as c-erb B2, HER2) is a proto-oncogene located on chromosome 17q 12-21 and encodes a 185-kDa transmembrane glycoprotein that belongs to the epidermal growth factor receptor family with tyrosine kinase activity in humans $(7,9,24)$. In canines, c-erb B2 is located on chromosome 1a13.1 (11). c-erb B2 is an important tumor marker and performs important functions such as regulating tumor growth, survival and differentiation $(1,10)$. Activation of c-erb B2, the intracellular signaling cascade of epidermal growth factor receptor is hyperactivated; as result, tumor cells grow faster than their normal rate, thus leading to the development of cancer $(11,25)$. It has been found to be approximately $30 \%$ expressed in canine mammary tumors as well as in human breast cancers $(2,9)$. In veterinary medicine, there is a positive correlation between c-erb b2 expression (based on data obtained from tissue and serum by ELISA or IHC methods) and mitotic tumor index, high histological grade, and tumor size (2). Although this information suggests that this gene is a significant marker associated with poor prognosis, different study data do not support this idea $(2,6,12)$. Certain criteria should be taken into consideration when evaluating tumor prognosis. These can be briefly summarized as follows; clinical stage, tumor size, metastasis to lymph node or distant tissues, lymphatic or vascular invasion, and histopathological type (2). Bertagnolli et al. 2011 (14), Rezaie et al. 2012 (24) and
Muhammadnejad et al. 2012 (11) think that there is a positive relationship between large tumor size, poor histological stage, malignancy, p53 expression and overexpression of c-erb B2. Similar to these studies $(11,14,24)$, we also found an increase in the number of c-erb B2 positive cells as the tumor size increased. In addition, we observed c-erb B2 immune positive reactions in the membrane $(4-6,9,14,15,26$ $29)$ and cytoplasm $(1,12,22,23)$ of neoplastic cells, in accordance with the literature studies. According to the data of our study, we think that c-erb B2 is a reliable marker in the detection and prognosis of canine mammary tumors.

Acting as a central mediator in sphingolipid metabolism, ceramide has emerged as a key regulatory molecule mediating various responses to stress stimuli in cancer $(16,19)$. It has been demonstrated that increased ceramide levels due to the use of ceramide analogs are highly effective in killing breast cancer and leukemia cells (16). UGCG, which has an antagonist effect on ceramide, is closely related to MDR and has been found to be highly expressed in various cancer types such as metastatic breast cancer with poor prognosis or colon cancer with poor prognosis (17-19). One of the main features of neoplastic disease is continuous and uncontrolled cell proliferation (19). Schömel et al. (19) found that the UGCG overexpression increased the proliferation of breast cancer cells. Surgery is the most effective treatment method for canine mammary tumors that have epidemiological, biological and clinical features similar to human breast tumors. Unlike human breast tumors, other systemic treatments cannot often be applied to canine mammary tumors (29). MDR of cancer cells is one of the most important causes of failure in treatment (17). This limited area of treatment options also increases the importance of immunohistochemical markers in the early diagnosis of canine breast tumors (1). In the literature reviews, no study was found in which UGCG was investigated immunohistochemically in canine mammary tumors. According to the results of our study, UGCG and the 
important oncogene c-erb B2 positive cell numbers increased in parallel with the tumor size.

In conclusion, the increase in the number of cerb B2 and UGCG positive cells in direct proportion to the tumor size (2), which is an important diagnostic parameter in canine mammary tumors, made us think that c-erb B2 and UGCG could be reliable markers in the diagnosis of canine mammary tumors. In addition, these markers must be evaluated comprehensively in line with different cancer diagnosis parameters.

\section{Conflict of interest}

The authors declare that they have no conflict of interest.

\section{REFERENCES}

1. Muniappan N., Ramesh S., Hemalatha S., Shafiuzama M., Preetha SP., 2019. Expression of biomarkers in canine mammary tumours. Int J Curr Microbiol App Sci, 8, 1464-1473.

2. Kaszak I., Ruszczak A., Kanafa S., Kacprzak K., Krol M., Jurka P., 2018. Current biomarkers of canine mammary tumors. Acta Vet Scand, 60, 66.

3. Mouser P., Miller MA., Antuofermo E., Badve SS., Mohammed SI., 2010. Prevalence and classification of spontaneous mammary intraepithelial lesions in dogs without clinical mammary disease. Vet Pathol, 47, 275-284.

4. Varallo GR., Gelaleti GB., Maschio-Signorini LB., Moschetta MG., Lopes JR., De Nardi AB., TinucciCosta M., Rocha RM., De Campos Zuccari DAP., 2019. Prognostic phenotypic classification for canine mammary tumors. Oncol Lett, 18, 65456553.

5. Gama A., Alves A., Schmitt F., 2008. Identification of molecular phenotypes in canine mammary carcinomas with clinical implications: application of the human classification. Virchows Arch, 453, 123-132.

6. Araujo MR., Campos LC., Damasceno KA., Gamba CO., Ferreira E., Cassali GD., 2016. HER-2, EGFR, Cox-2 and Ki67 expression in lymph node metastasis of canine mammary carcinomas: Association with clinical-pathological parameters and overall survival. Res Vet Sci, 106, 121-130.

7. Ressel L., Puleio R., Loria GR., Vannozzi I., Millanta F., Caracappa S., Poli A., 2013. HER-2 expression in canine morphologically normal, hyperplastic and neoplastic mammary tissues and its correlation with the clinical outcome. Res Vet Sci, 94, 299-305.

8. Martin de las Mulas J., Ordas J., Millan Y., Fernandez-Soria V., Ramon y Cajal S., 2003. Oncogene HER-2 in canine mammary gland carcinomas: an immunohistochemical and chromogenic in situ hybridization study. Breast Cancer Res Treat, 80, 363-367.

9. Hsu WL., Huang HM., Liao JW., Wong ML., Chang SC., 2009. Increased survival in dogs with malignant mammary tumours overexpressing HER-2 protein and detection of a silent single nucleotide polymorphism in the canine HER-2 gene. Vet J, 180, 116-123.

10. Kim JH., Im KS., Kim NH., Yhee JY., Nho WG., Sur $\mathrm{JH} ., 2011$. Expression of HER-2 and nuclear localization of HER-3 protein in canine mammary tumors: histopathological and immunohistochemical study. Vet J, 189, 318322.

11. Muhammadnejad A., Keyhani E., Mortazavi P., Behjati F., Haghdoost IS., 2012. Overexpression of her-2/neu in malignant mammary tumors; translation of clinicopathological features from dog to human. Asian Pac J Cancer Prev, 13, 6415 6421.

12. Rungsipipat A., Tangkawatana S., Sailasuta A., Lohachit C., Chariyalertsak S., 2008. C-erbB-2 oncogene and P21WAF/CIP1 tumor suppressor gene expression as prognostic factors in canine mammary adenocarcinomas. Comp Clin Pathol, $17,35-41$.

13. Queiroga FL., Raposo T., Carvalho MI., Prada J., Pires I., 2011. Canine mammary tumours as a model to study human breast cancer: most 
recent findings. In Vivo, 25, 455-466.

14. Bertagnolli AC., Ferreira E., Dias EJ., Cassali GD., 2011. Canine mammary mixed tumours: immunohistochemical expressions of EGFR and HER-2. Aust Vet J, 89, 312-317.

15. Pena L., Gama A., Goldschmidt MH., Abadie J., Benazzi C., Castagnaro M., Diez L., Gartner F., Hellmen E., Kiupel M., Millan Y., Miller MA., Nguyen F., Poli A., Sarli G., Zappulli V., de las Mulas JM., 2014. Canine mammary tumors: a review and consensus of standard guidelines on epithelial and myoepithelial phenotype markers, HER2, and hormone receptor assessment using immunohistochemistry. Vet Pathol, 51, 127-145.

16. Che J., Huang Y., Xu C., Zhang P., 2017. Increased ceramide production sensitizes breast cancer cell response to chemotherapy. Cancer Chemother Pharmacol, 79, 933-941.

17. Wegner MS., Schömel N., Gruber L., Örtel SB., Kjellberg MA., Mattjus P., Kurz J., Trautmann S., Peng B., Wegner M., Kaulich M., Ahrends R., Geisslinger G., Grösch S., 2018. UDP-glucose ceramide glucosyltransferase activates AKT, promoted proliferation, and doxorubicin resistance in breast cancer cells. Cell Mol Life Sci, 75, 3393-3410.

18. Schömel N., Hancock SE., Gruber L., Olzomer EM., Byrne FL., Shah D., Hoehn KL., Turner N., Grösch S., Geisslinger G., Wegner MS., 2019. UGCG influences glutamine metabolism of breast cancer cells. Sci Rep, 9, 15665.

19. Schömel N., Gruber L., Alexopoulos SJ., Trautmann S., Olzomer EM., Byrne FL., Hoehn KL., Gurke R., Thomas D., Ferreiros N., Geisslinger G., Wegner MS., 2020. UGCG overexpression leads to increased glycolysis and increased oxidative phosphorylation of breast cancer cells. Sci Rep, 10, 8182.

20. Al-Mansour MA., Kubba MAG., Al-Azreg SA., Dribika SA., 2018. Comparative histopathology and immunohistochemistry of human and canine mammary tumors. Open Vet J, 8, 243 249.

21. Dutra AP., Granja NV., Schmitt FC., Cassali GD., 2004. c-erbB-2 expression and nuclear pleomorphism in canine mammary tumors. Braz J Med Biol Res, 37, 1673-1681.

22. Rungsipipat A., Tateyama S., Yamaguchi R., Uchida K., Miyoshi N., Hayashi T., 1999. Immunohistochemical analysis of c-yes and cerbB-2 oncogene products and p53 tumor suppressor protein in canine mammary tumors. J Vet Med Sci, 61, 27-32.

23. Winston J., Craft DM., Scase TJ., Bergman PJ., 2005. Immunohistochemical detection of HER$2 /$ neu expression in spontaneous feline mammary tumours. Vet Comp Oncol, 3, 8-15.

24. Rezaie A., Tavasoli A., Mehrazma M., Bahonar A., 2012. c-erbB2 receptor and P53 protein expression in canine mammary gland carcinoma. Comp Clin Pathol, 21, 1633-1636.

25. Pedraza-Ordonez F., Montoya-Florez LM., Bulla C., Rocha NS., 2015. Analisys of immunohistochemical prognostic markers in canine mammary cancer and its relation to postsurgical survival. OJ Pathology, 5, 90-99.

26. Singer J., Weichselbaumer M., Stockner T., Mechtcheriakova D., Sobanov Y., Bajna E., Wrba F., Horvat R., Thalhammer JG., Willmann M., Jensen-Jarolim E., 2012. Comparative oncology: ErbB-1 and ErbB-2 homologues in canine cancer are susceptible to cetuximab and trastuzumab targeting. Mol Immunol, 50, 200-209.

27. Muscatello LV., Sarli G., Beha G., Asproni P., Millanta F., Poli A., De Tolla LJ., Benazzi C., Brunetti B., 2015. Validation of tissue microarray for molecular profiling of canine and feline mammary tumours. J Comp Pathol, 152, 153160.

28. Klopfleisch R., Klose P., Weise C., Bondzio A., Multhaup G., Einspanier R., Gruber AD., 2010. Proteome of metastatic canine mammary carcinomas: similarities to and differences from human breast cancer. J Proteome Res, 9, 63806391.

29. Seung BJ., Cho SH., Kim SH., Lim HY., Sur JH., 2020. Quantitative analysis of HER2 mRNA expression by RNA in situ hybridization in canine mammary gland tumors: Comparison with immunohistochemistry analysis. PLoS One, 15, e0229031. 